DOI:10.31933/DIJMS

Received: $11^{\text {th }}$ August 2020, Revised: $15^{\text {th }}$ September 2020, Publish: $12^{\text {nd }}$ November 2020

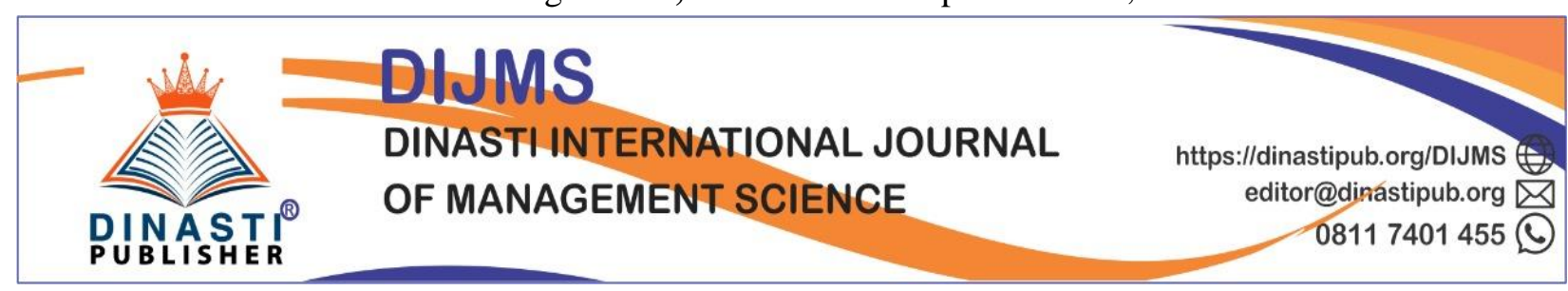

\title{
EFFECT OF INTERNAL AUDIT QUALITY ON THE EFFECTIVENESS OF GOOD CORPORATE GOVERNANCE (CASE STUDY AT PT JASA RAHARJA)
}

\author{
Fajar Arya Adhitya Putra', Hadri Mulya ${ }^{2)}$ \\ 1) Master of Accounting Study Program, Postgraduate of Universitas Mercu Buana, Indonesia, \\ fajararya0807@gmail.com \\ 2) Master of Accounting Study Program, Postgraduate of Universitas Mercu Buana, Indonesia, \\ hadrimulya@yahoo.co.id
}

\section{Corresponding Author: First Author}

Abstract: This study aims to examine the Effect of Internal Audit Quality on the Effectiveness of Good Corporate Governance which is seen from the Independence of Auditors, Professional Capabilities, Scope of Work and Examination at PT Jasa Raharja.The population in this study were all employees of PT Jasa Raharja which were divided into Employees of the Internal Control Unit, Head of Branches, Head of Division, Head of Internal Control Unit and Corporate Secretary of PT Jasa Raharja. Samples obtained by purposive sampling method were as many as 85 employees. The results of statistical tests show that the Quality of Internal Audit has a significant effect on the Effectiveness of Good Corporate Governance that is measured using variables such as Independence, Professional Capability, Scope of Work and Examination.

Keywords: Internal Audit Quality (Independence, Professional Capability, Scope of Work, Examination), Good Corporate Governance

\section{INTRODUCTION}

The issue of Good Corporate Governance is now a concern because it is expected to bring various benefits to the company. These benefits include: reducing risk, helping to ensure compliance with existing regulations, increasing leadership in the company, improving performance, helping companies that go public, increasing shareholder trust, and expressing social accountability clearly. The efforts made by the government in realizing good corporate governance to improve the performance of State-Owned Enterprises in Indonesia are the issuance the Minister of State-Owned Enterprises's decision number: KEP-117 / M-MBU / 2002 concerning the Implementation of Good Corporate Governance Practices in State-Owned Enterprises.

The purpose of implementing good corporate governance is to encourage transparency in reporting on company operations both financial and non-financial. This is an effort to protect 
the rights of stakeholders towards the company. The separation between the principal (company owner) and the agent (management in the company) is thought to cause information asymmetry between the two parties because the management or agent has more complete information about the actual condition of the company than the principal. A good corporate governance system is made to be able to reduce information asymmetry so that companies can carry out operations more effectively and efficiently, then the objectives of the company can be achieved. A good corporate governance system must provide effective protection to stakeholders, so that they can convince themselves to get back the benefits properly. The system must also help create a conducive and sustainable environment. Thus Corporate Governance can be interpreted as effective Good Corporate Governance.

The existence of internal audits in the company is expected to be able to encourage companies to implement a good corporate governance system to the maximum so that the goals of the company can be more directed and the company's operational activities can run effectively and efficiently. Tones and Bare (1990) revealed that Internal Audit can encourage the creation of Good Corporate Governance which ultimately can reduce fraud. Quality internal audit will contribute to the creation of an effective corporate governance within the organization, which includes all policies and procedures managed by management to control risks and oversee the operations of the company (Messier et.al, 2008). The quality of Internal Audit according to The Standards for The Professional Practice of Internal Auditing and Akmal (2007; 3) can be seen from independence, professional ability, scope of work and implementation of examinations. This statement is reinforced by several results of research and experts including Hiro Tugiman (2006), (Messier et, al 2008), Ratliff in Arent et al (2005), Bodnar (2005), Boynton (2003) and Arent (2005).

The Indonesian Internal Auditor Professional Organization mentions the relationship between internal audit and good corporate governance in position paper \# 1/2003, namely: "Internal Auditor Professional Organizations believe that an effective internal audit function is able to offer important contributions in improving the corporate governance process, risk management and management control, internal auditors are important support for commissioners, audit committees, directors and senior management in forming the foundation for the development of corporate governance ".The purpose of this study is to examine the effect of internal audit factors which include independence, professional ability, scope of work, and the Examination on the effectiveness of good corporate governance at PT Jasa Raharja.

\section{LITERATURE REVIEW} Agency Theory

Jensen and Meckling (1976) describe agency relations in agency theory that a company is a collection of contracts between the owner of economic resources (principal) and the manager (agent) who manages the use and control of these resources.

The theory agency results in an asymmetrical relationship between the owner and the manager, to avoid a relationship that is asymmetry requires a concept of Good Corporate 
Governance that aims to make the company better. Corporate governance in agency theory can be explained by the relationship between management and the owner, management as an agent is morally responsible for optimizing the profits of the owner (principal) and in return will receive compensation in accordance with the contract.

\section{Theory of Attitude and Behavior}

Saifuddin Azwar (2012: 88) "Attitudes are certain regularities in terms of feelings (affections), thoughts (cognitive), and predisposing actions (konasi) of someone to an aspect of the surrounding environment". Attitude and behavior theory is a theory that states that a person's behavior is determined by attitudes, social rules, habits and knowing the consequences of these behaviors. The attitude and behavior theory wants to explain about the attitude held by someone to determine a person's behavior.

Attitudes and behavior are often said to be closely related. The results of several studies also show a strong relationship between attitudes and behavior. This attitude and behavior theory only describes attitudes that can lead to behavior. In this study, attitudinal and behavioral theories can be used to explain the independent and objectivity and the professional abilities of internal auditors towards audit quality.

\section{Quality of Internal Audit}

The concept of quality in this study is quality in terms of internal audit performance. In the sense that the internal audit is said to be of quality if the internal audit implements the professional standards and the established internal audit code of ethics.

\section{Internal Audit}

According to the IIA the Board of Directors the definition of Internal Audit:

"Internal auditing is an independent, objective assurance and consulting activiting designed to add value and improve an organization's operation.It helps an organization accomplish its objectives by bringing a systematic, discliplined approach to evaluate and improve the effectiveness of risk management, control, and governance procesesses"

According to Mulyadi (2014: 9) audit is: A systematic process to obtain and evaluate evidence objectively about statements of activities and economic events, with the aim of determining the level of conformity between the statements with the criteria that have been set, and the delivery of results to interested users. Audit according to Arens et al (2015: 2) is the collection and evaluation of evidence about information to determine and report the degree of conformity between that information and predetermined criteria.

From the various meanings above, it can be said that the audit is a process of examination carried out systematically on financial statements, internal supervision, and accounting records of a company. Audit aims to evaluate and provide opinions regarding the fairness of financial statements based on the evidence obtained and carried out by an independent and competent person.

\section{The Effectiveness of Good Corporate Governance}

The definition of the effectiveness of Good Corporate Governance in this study is that the company has implemented the principles of Good Corporate Governance in accordance with 
what has been determined and expected. Effective implementation of corporate governance requires an understanding of GCG principles that include:

1. Responsibility; ensures that companies are managed carefully in accordance with applicable laws and regulations, including establishing appropriate risk management and control

2. Accountability; means the demand that company management has the ability to answerability, namely the ability to respond to questions from stakeholders on various corporate actions carried out

3. Fairness; guarantees the protection of the rights of shareholders, management and employees, consumers and other stakeholders

4. Transparency; means the availability of accurate, relevant and easy to understand information that can be obtained in low-cost so that stakeholders can make the right decisions. Therefore, companies need to improve the quality, quantity and frequency of company activity reports

5. Independency; acts only in the interests of the company and is not influenced by activities that lead to the emergence of conflict of interest.

\section{Conceptual Framework}

Quality internal audit will contribute to the creation of an effective corporate governance within the organization, which includes all policies and procedures managed by management to control risks and oversee the operations of the company (Messier et.al, 2008). The quality of Internal Audit according to The Standards for The Professional Practice of Internal Auditing and Akmal $(2007$; 3) can be seen from independence and objectivity, professional ability, scope of work and implementation of examinations.

The main problems in companies going public are generally having good corporate governance values that are relatively less effective. The Indonesian Internal Auditor Professional Organization believes that quality internal audits will be able to offer important contributions in increasing the effectiveness of good corporate governance, namely in forming the foundation for the development of corporate governance. This statement is reinforced by several results of research and experts including Hiro Tugiman (2006), (Messier et, al 2008), Ratliff in Arent et al (2005), Bodnar (2005), Boynton (2003) and Arent (2005).

The importance of independence in good corporate governance is revealed by Daniri (2005) which states that internal audit is one of the important elements supporting the effectiveness of good corporate governance.

The importance of internal audit professionalism in the implementation of good corporate governance is disclosed by Leung et al. (2002) which states that in carrying out the role of internal audit in corporate governance and to maintain the trust of stakeholders internal audit must work with the ability of good professionals with knowledge and skills . Furthermore Ruud (2003) also states that in carrying out its duties to improve effective governance, the internal audit function requires knowledge, skills and abilities.

Tugiman $(2003 ; 41)$ states that the scope of the internal audit work must include testing and evaluating the adequacy and effectiveness of the internal control system owned by the organization and the quality of implementing responsibilities. Audit activities implementation of work must include planning checks, testing and evaluating information, notifying results, and following up on audit results.

The Indonesian Internal Auditor Professional Organization mentions the relationship between internal audit and good corporate governance in position paper \# 1/2003, namely: "Internal Auditor Professional Organizations believe that an effective internal audit function is 
able to offer important contributions in improving the corporate governance process, risk management and management control, internal auditors are important support for commissioners, audit committees, directors and senior management in forming the foundation for the development of corporate governance".

This from the above mindset it is assumed that the quality of internal audit will contribute to the effectiveness of good corporate governance, so that researchers will further examine the truth by conducting testing and research. The research that will be carried out on internal audit is seen from its quality aspect, while good corporate governance is seen from the aspect of its effectiveness.

Based on the description above, thus framework of thinking can be described as follows:

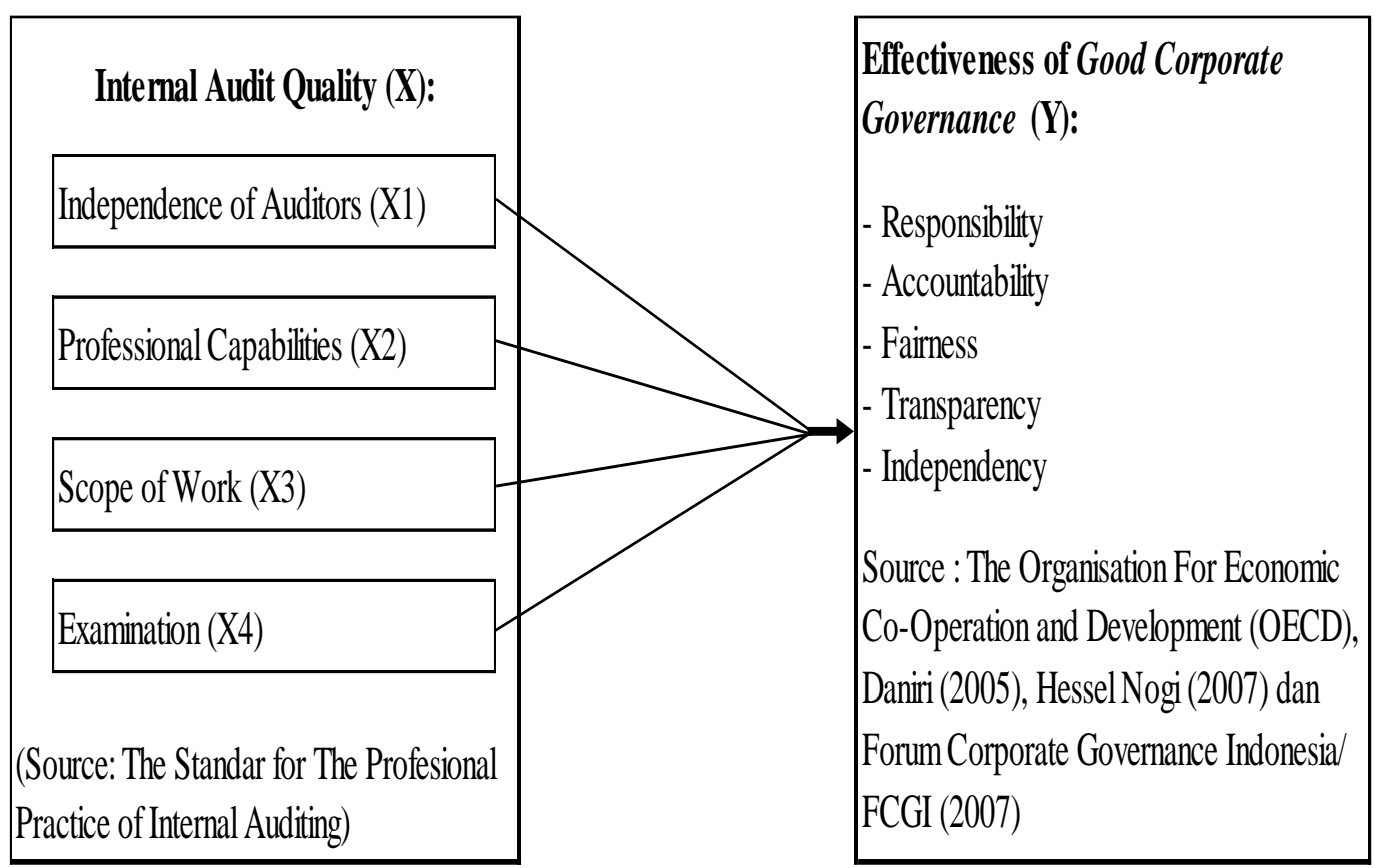

Figure 1. Conceptual Framework

\section{RESEARCH METHODS}

The method used in this research is verification analysis. According to Nazir (2011: 91) "Verification method is a research method that aims to find out the causal relationship (causal relationship) between variables through a hypothesis testing using a statistical calculation so that the results obtained prove that the hypothesis is rejected or accepted".

Research with this verification approach is used to determine the effect of internal audit quality which includes four dimensions (independence, professional ability, scope of work, and examination) on the effectiveness of good corporate governance.

\section{Operational Definition of Variables}

Independent and Dependent Variable Operational Table 


\begin{tabular}{|c|c|c|c|c|}
\hline Variable & & Dimension & Indicator & $\begin{array}{c}\text { Measur } \\
\text { ement } \\
\text { Scale }\end{array}$ \\
\hline $\begin{array}{l}\text { Internal Audit } \\
\text { Quality (X) } \\
\text { (The Standar } \\
\text { for The } \\
\text { Profesional } \\
\text { Practice of } \\
\text { Internal } \\
\text { Auditing, } \\
\text { Akmal, 2007) }\end{array}$ & 3) & $\begin{array}{l}\text { Independence } \\
\text { of Auditor } \\
\left(\mathrm{X}_{1}\right) \\
\text { Professional } \\
\text { Capabilities } \\
\left(\mathrm{X}_{2}\right)\end{array}$ & 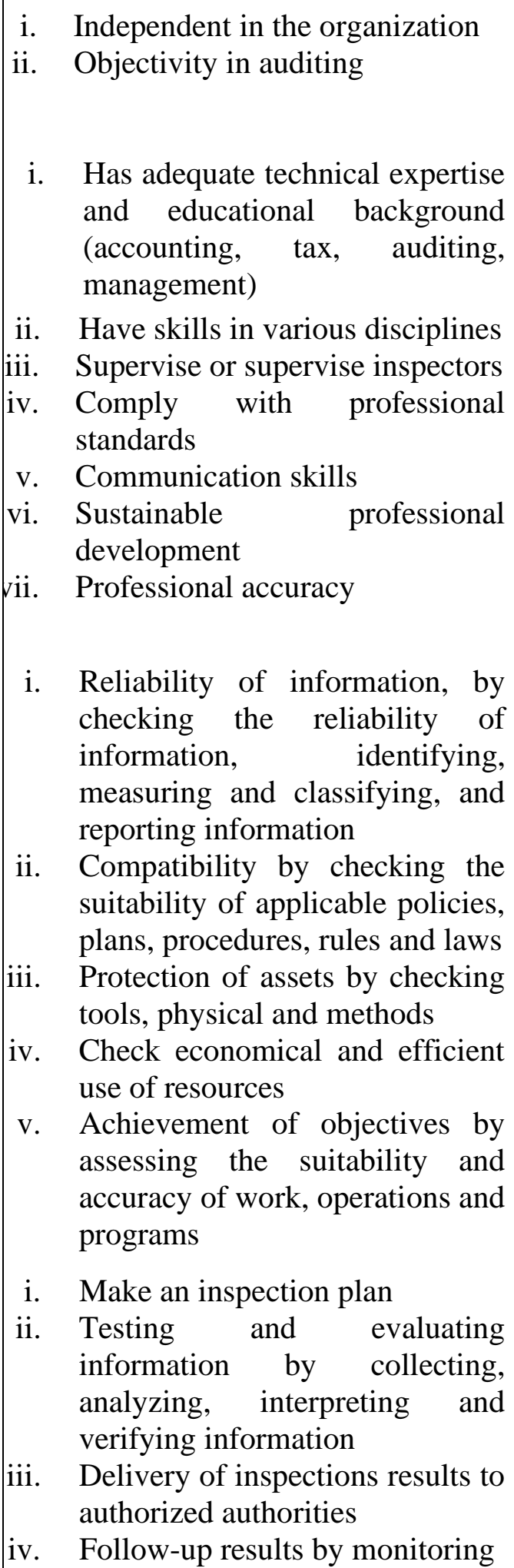 & Ordinal \\
\hline
\end{tabular}




\begin{tabular}{|c|c|c|c|}
\hline Variable & Dimension & Indicator & $\begin{array}{c}\text { Measur } \\
\text { ement } \\
\text { Scale }\end{array}$ \\
\hline $\begin{array}{l}\text { Effectiveness } \\
\text { of Good } \\
\text { Corporate } \\
\text { Governance } \\
\text { (Y) } \\
\text { The } \\
\text { Organisation } \\
\text { For Economic } \\
\text { Co-Operation } \\
\text { and } \\
\text { Development } \\
\text { (OECD), } \\
\text { Daniri } \\
\text { (2005), } \\
\text { Hessel Nogi } \\
\text { (2007) dan } \\
\text { Forum } \\
\text { Corporate } \\
\text { Governance } \\
\text { Indonesia/ } \\
\text { FCGI (2007) }\end{array}$ & 1) Responsibility & 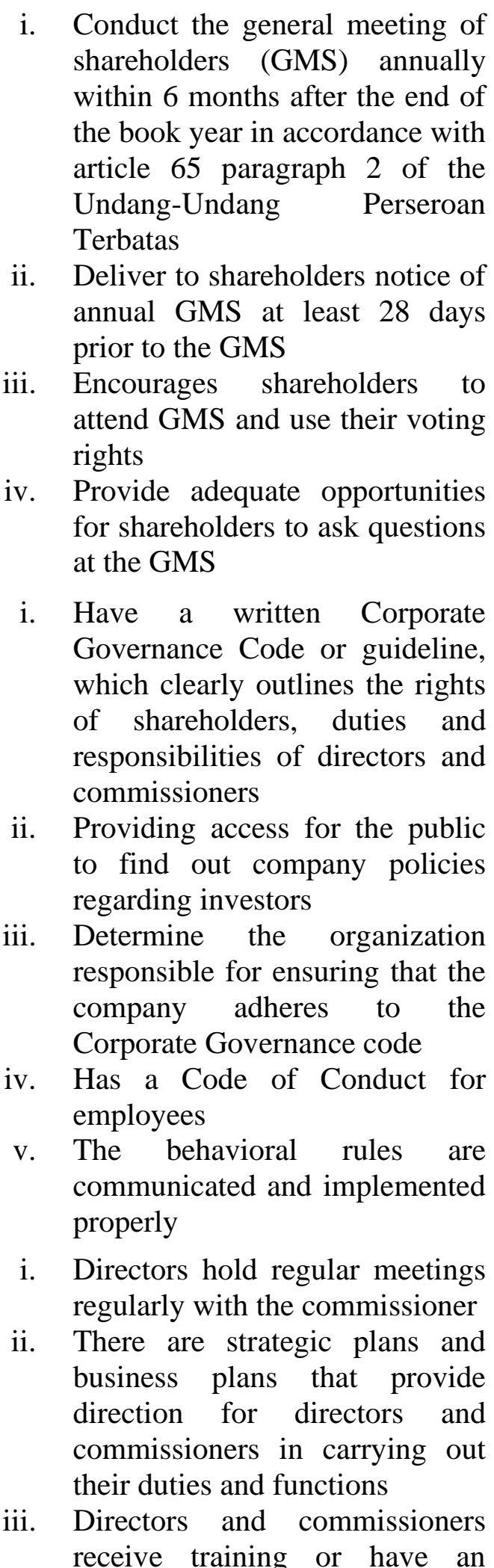 & Ordinal \\
\hline
\end{tabular}




\begin{tabular}{|c|c|c|c|}
\hline Variable & Dimension & Indicator & $\begin{array}{c}\text { Measur } \\
\text { ement } \\
\text { Scale }\end{array}$ \\
\hline & 4) Transparency & 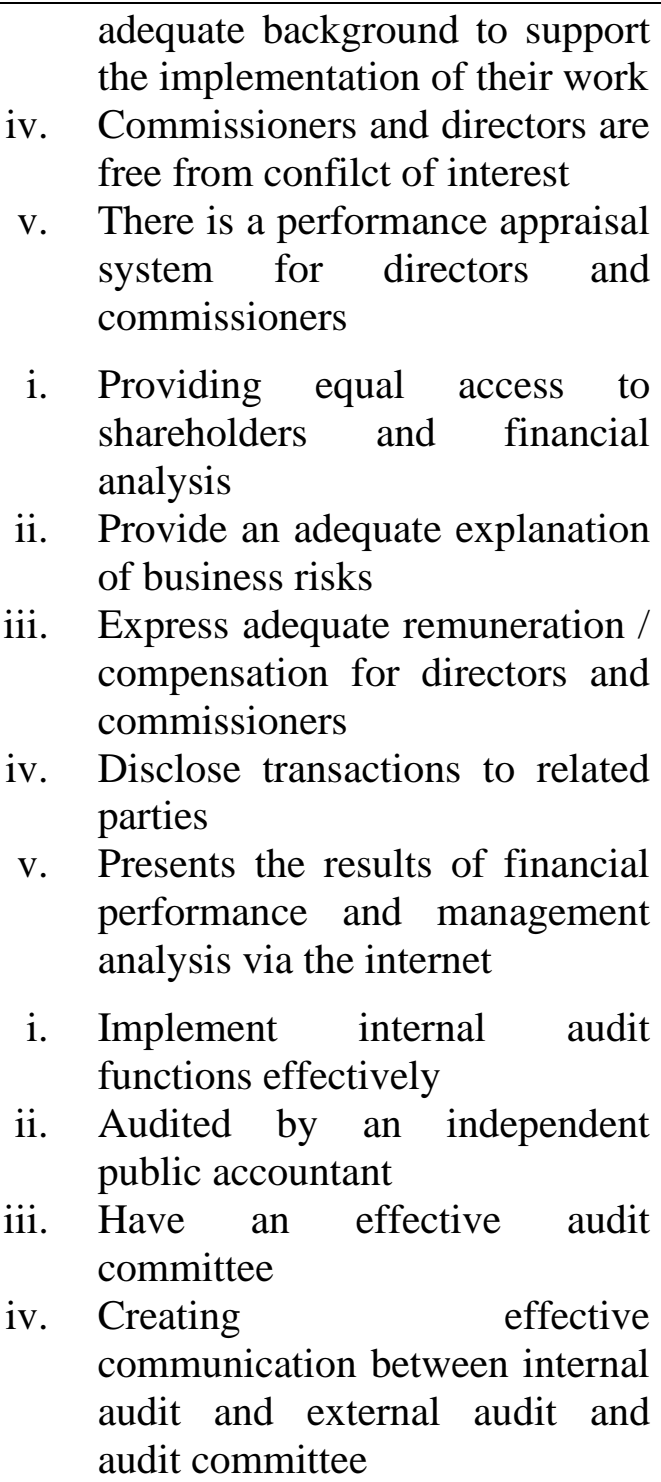 & \\
\hline
\end{tabular}

\section{Research Population and Samples}

Population is the whole group of people, events or things you want to investigate (Sekaran, 2013). The population in this study were all employees working at PT. Jasa Raharja (Persero) as many as 2,052 people.

The sample is to select a sufficient number of elements from the population so that research on the sample allows us to generalize these characteristics or characteristics to the population elements (Sekaran, 2013). In determining the sample used in this study, the researcher used a purposive sampling technique. According to Sugiyono (2014: 122) the meaning of purposive slamping is as follows:

"Purposive sampling is a technique of determining samples with certain considerations ". 
The reason for using purposive sampling technique is because not all samples have criteria that are in accordance with what the researcher has determined. Therefore, researchers chose a purposive sampling technique by determining certain considerations or criteria that must be met by the samples used in this study. The criteria used as samples of this study are as follows:

1) Employees of the Internal Control Unit at PT. Jasa Raharja (Persero)

2) Head of Branches PT. Jasa Raharja (Persero) throughout Indonesia

3) Head of Division PT. Jasa Raharja (Persero) Head Office

4) Head of Internal Control Unit PT. Jasa Raharja (Persero)

5) Company Secretary PT. Jasa Raharja (Persero).

Taking research samples can be see in the table

Table 1. Population and Sampling Table

\begin{tabular}{|c|l|c|}
\hline No. & \multicolumn{1}{|c|}{ Criteria } & People \\
\hline 1 & Employees of the Internal Control Unit PT. Jasa Raharja & $\mathbf{4 5}$ \\
\hline 2 & $\begin{array}{l}\text { Head of Branches PT. Jasa Raharja (Persero) throughout } \\
\text { Indonesia }\end{array}$ & $\mathbf{2 9}$ \\
\hline 3 & Head of Division PT. Jasa Raharja (Persero) Head Office & $\mathbf{9}$ \\
\hline 4 & Head of Internal Control Unit PT. Jasa Raharja (Persero) & $\mathbf{1}$ \\
\hline 5 & Company Secretary PT. Jasa Raharja (Persero) & $\mathbf{1}$ \\
\hline \multicolumn{2}{|r|}{ Total Sample } & $\mathbf{8 5}$ \\
\hline
\end{tabular}

FINDINGS AND DISCUSSION

1. Validity and Reliability Test

Table 2. Tests for Validity of Variable Quality of Internal Audit

\begin{tabular}{|c|c|c|c|c|}
\hline Variable & Item & $\begin{array}{c}\text { Coefficient of } \\
\text { Validity }\end{array}$ & $\begin{array}{c}\text { R Table } \\
\text { Value }\end{array}$ & Criteria \\
\hline \multirow{22}{*}{$\begin{array}{c}\text { Internal Audit } \\
\text { Quality }\end{array}$} & $\mathrm{P} 1$ & 0.490 & 0.177 & Valid \\
\hline & $\mathrm{P} 2$ & 0.613 & 0.177 & Valid \\
\hline & P3 & 0.312 & 0.177 & Valid \\
\hline & $\mathrm{P} 4$ & 0.476 & 0.177 & Valid \\
\hline & P5 & 0.347 & 0.177 & Valid \\
\hline & P6 & 0.252 & 0.177 & Valid \\
\hline & P7 & 0.444 & 0.177 & Valid \\
\hline & P8 & 0.568 & 0.177 & Valid \\
\hline & P9 & 0.320 & 0.177 & Valid \\
\hline & P10 & 0.404 & 0.177 & Valid \\
\hline & P11 & 0.421 & 0.177 & Valid \\
\hline & P12 & 0.306 & 0.177 & Valid \\
\hline & P13 & 0.261 & 0.177 & Valid \\
\hline & P14 & 0.522 & 0.177 & Valid \\
\hline & $\mathrm{P} 15$ & 0.456 & 0.177 & Valid \\
\hline & P16 & 0.568 & 0.177 & Valid \\
\hline & P17 & 0.562 & 0.177 & Valid \\
\hline & P18 & 0.520 & 0.177 & Valid \\
\hline & P19 & 0.654 & 0.177 & Valid \\
\hline & $\mathrm{P} 20$ & 0.388 & 0.177 & Valid \\
\hline & P21 & 0.411 & 0.177 & Valid \\
\hline & $\mathrm{P} 22$ & 0.445 & 0.177 & Valid \\
\hline
\end{tabular}


Source: Results of Primary Data Processing, 2018

Table 3. Tests for Reliability of Variable Quality of Internal Audit

\begin{tabular}{|c|c|c|}
\hline Variable & Cronbach Alpha Value & Criteria \\
\hline Internal Audit Quality & 0.756 & Reliabel \\
\hline
\end{tabular}

Source: Results of Primary Data Processing, 2018

Table 4. Tests for Validity of Variable Good Corporate Governance

\begin{tabular}{|c|c|c|c|c|}
\hline Variable & Item & $\begin{array}{c}\text { Coefficient of } \\
\text { Validity } \\
\end{array}$ & $\begin{array}{c}\text { R Table } \\
\text { Value }\end{array}$ & Criteria \\
\hline \multirow{28}{*}{$\begin{array}{c}\text { Good Corporate } \\
\text { Governance }\end{array}$} & $\mathrm{P} 23$ & 0.240 & 0.177 & Valid \\
\hline & $\mathrm{P} 24$ & 0.673 & 0.177 & Valid \\
\hline & $\mathrm{P} 25$ & 0.495 & 0.177 & Valid \\
\hline & $\mathrm{P} 26$ & 0.305 & 0.177 & Valid \\
\hline & $\mathrm{P} 27$ & 0.229 & 0.177 & Valid \\
\hline & $\mathrm{P} 28$ & 0.286 & 0.177 & Valid \\
\hline & P29 & 0.370 & 0.177 & Valid \\
\hline & $\mathrm{P} 30$ & 0.415 & 0.177 & Valid \\
\hline & P31 & 0.402 & 0.177 & Valid \\
\hline & $\mathrm{P} 32$ & 0.327 & 0.177 & Valid \\
\hline & $\mathrm{P} 33$ & 0.192 & 0.177 & Valid \\
\hline & P34 & 0.209 & 0.177 & Valid \\
\hline & $\mathrm{P} 35$ & 0.365 & 0.177 & Valid \\
\hline & $\mathrm{P} 36$ & 0.316 & 0.177 & Valid \\
\hline & P37 & 0.372 & 0.177 & Valid \\
\hline & P38 & 0.451 & 0.177 & Valid \\
\hline & P39 & 0.217 & 0.177 & Valid \\
\hline & $\mathrm{P} 40$ & 0.204 & 0.177 & Valid \\
\hline & $\mathrm{P} 41$ & 0.278 & 0.177 & Valid \\
\hline & $\mathrm{P} 42$ & 0.270 & 0.177 & Valid \\
\hline & $\mathrm{P} 43$ & 0.404 & 0.177 & Valid \\
\hline & $\mathrm{P} 44$ & 0.688 & 0.177 & Valid \\
\hline & $\mathrm{P} 45$ & 0.276 & 0.177 & Valid \\
\hline & $\mathrm{P} 46$ & 0.390 & 0.177 & Valid \\
\hline & $\mathrm{P} 47$ & 0.278 & 0.177 & Valid \\
\hline & $\mathrm{P} 48$ & 0.722 & 0.177 & Valid \\
\hline & $\mathrm{P} 49$ & 0.266 & 0.177 & Valid \\
\hline & $\mathrm{P} 50$ & 0.388 & 0.177 & Valid \\
\hline
\end{tabular}

Table 5. Tests for Reliability of Variable Good Corporate Governance

\begin{tabular}{|c|c|c|}
\hline Variable & Cronbach Alpha Value & Criteria \\
\hline Good Corporate Governance & 0.725 & Reliabel \\
\hline
\end{tabular}

\section{Data Normality Test}


Table 6. Data Normality Test

One-Sample Kolmogorov-Smirnov Test

\begin{tabular}{|ll|r|}
\hline & & \multicolumn{1}{|c|}{ Unstandardized Residual } \\
\hline $\mathrm{N}$ & & 85 \\
Normal Parameters ${ }^{\mathrm{a}, \mathrm{b}}$ & Mean & .0000000 \\
& Std. Deviation & 2.84501027 \\
\cline { 2 - 3 } Most Extreme Differences & Absolute & .090 \\
\cline { 2 - 3 } & Positive & .090 \\
& Negative & -.054 \\
\cline { 2 - 3 } Test Statistic & & .090 \\
Asymp. Sig. (2-tailed) & & $.089^{\mathrm{c}}$ \\
\hline
\end{tabular}

a. Test distribution is Normal.

b. Calculated from data.

c. Lilliefors Significance Correction.

Source: Results of Primary Data Processing, 2018

\section{F Test}

Table 7. F Test

F Test Value the Effect of Independence, Professional Capability, Scope of

Work, and Examination

to Good Corporate Governance

ANOVA

\begin{tabular}{|c|c|c|c|c|c|}
\hline Model & Sum of Squares & df & $\begin{array}{l}\text { Mean } \\
\text { Square }\end{array}$ & $\mathrm{F}$ & Sig. \\
\hline 1 Regression & 1222.144 & 4 & 305.536 & 35.951 & $.000^{\mathrm{b}}$ \\
\hline Residual & 679.903 & 80 & 8.499 & & \\
\hline Total & 1902.047 & 84 & & & \\
\hline
\end{tabular}

a. Dependent Variable: Good Corporate

b. Predictors: (Constant), Independence, Professional Capability, Scope of

Work.Examination 


\section{T Test}

Table 8. T Test Regression Analysis of Independence, Professional Capability, Scope of Work
and Examination of Good Corporate Governance

\begin{tabular}{|c|c|c|c|c|c|c|}
\hline \multicolumn{7}{|c|}{ Coefficients ${ }^{\mathrm{a}}$} \\
\hline \multirow{2}{*}{\multicolumn{2}{|c|}{ Model }} & \multicolumn{2}{|c|}{$\begin{array}{l}\text { Unstandardized } \\
\text { Coefficients }\end{array}$} & \multirow{3}{*}{$\begin{array}{c}\text { Standardized } \\
\text { Coefficients }\end{array}$} & \multirow{3}{*}{$\begin{array}{c}\mathrm{t} \\
3.555\end{array}$} & \multirow{3}{*}{$\begin{array}{l}\text { Sig. } \\
0.001\end{array}$} \\
\hline & & \multirow{2}{*}{$\begin{array}{c}\mathrm{B} \\
22.935\end{array}$} & \multirow{2}{*}{$\begin{array}{c}\begin{array}{c}\text { Std. } \\
\text { Error }\end{array} \\
6.451\end{array}$} & & & \\
\hline \multirow{5}{*}{1} & (Constant) & & & & & \\
\hline & Independence & 0.676 & 0.217 & 0.24 & 3.116 & 0.003 \\
\hline & $\begin{array}{l}\text { Professional } \\
\text { Capabilities }\end{array}$ & 0.445 & 0.205 & 0.215 & 2.174 & 0.033 \\
\hline & Scope of Work & 0.867 & 0.385 & 0.2 & 2.254 & 0.027 \\
\hline & Examination & 1.894 & 0.507 & 0.347 & 3.736 & 0 \\
\hline \multicolumn{7}{|c|}{ Dependent Variable: Good Corporate Governance } \\
\hline
\end{tabular}

Source: Results of Primary Data Processing, 2018

\section{The Effect of Independence on Good Corporate Governance}

Based on the results obtained it can be analyzed that the direction of the relationship of Independence with Good Corporate Governance is positive, there is written 0.676 meaning that when there is an increase in Independence it will improve Good Corporate Governance. Based on the provisions previously stated, where a t-count of 3,116 is obtained and the degree of freedom (n-k-1) or 85-4-1 = 80 a t-table number of 1,990 is obtained, so that $\mathrm{t}$-count $>\mathrm{t}$ table. This means that $\mathrm{H} 0$ is rejected and $\mathrm{H} 1$ is accepted, then there is a significant influence between Independence on Good Corporate Governance. Thus the hypothesis which states that there is an influence between Independence on Good Corporate Governance can be accepted. That independence carried out by auditors greatly influences the implementation of Good Corporate Governance in PT Jasa Raharja (Persero) so that the creation of good corporate governance in the company.

This happens because Internal Audit has been very objective in the sense of having an objective, impartial mental attitude and avoiding the possibility of conflict of interest. The results of this study are consistent with the theory put forward by Akmal (2007: 13), that Internal Audit is free and separate from the activities that it inspects.

This result is in line with research conducted by Dimas Sumadyo (2014) and Ayuthia Ramadhani Herman, Andreas, Hardi (2013) states that the independence of internal auditors with Good Corporate Governance has a close relationship and also has a positive direction.

\section{The Effect of Professional Capabilitiy on Good Corporate Governance}

Based on the results obtained, it can be analyzed that the direction of the relationship of Professional Capability with Good Corporate Governance is positive, there is written 0.445 meaning that when there is Professional Capability, it will improve Good Corporate Governance. Based on the provisions previously stated, where a t-count of 2,174 is obtained and the degree of freedom (n-k-1) or 85-4-1 = 80 a t-table number of 1,990 is obtained, so that $\mathrm{t}$-count $>\mathrm{t}$-table. This means that $\mathrm{H} 0$ is rejected and $\mathrm{H} 2$ is accepted, then there is a significant influence between Professional Capability on Good Corporate Governance. Thus the 
hypothesis which states that there is an influence between Professional Capability to Good Corporate Governance can be accepted. That the auditor's professional capability greatly influences the implementation of Good Corporate Governance at PT Jasa Raharja (Persero) so as to create good corporate governance in the company.

This is because the Internal Audit has or has acquired knowledge, skills and scientific disciplines that are important in carrying out audits and has complied with applicable audit standards. The results of this study are in accordance with the theory revealed by Akmal (2007).

This result is in line with research conducted by Gusnardi (2008) if internal audit has good professional skills in accordance with professional regulations and standards, it will be able to improve the implementation of good corporate governance.

\section{The Effect of Scope of Work on Good Corporate Governance}

Based on the results obtained it can be analyzed that the direction of the relationship between the Scope of Work with Good Corporate Governance is positive, there is written 0.867 meaning that when there is an increase in the Scope of Work it will improve Good Corporate Governance. Based on the provisions previously stated, where a t-count of 2,254 is obtained and the degree of freedom (n-k-1) or 85-4-1 = 80 a t-table number of 1,990 is obtained, so that $\mathrm{t}$-count $>\mathrm{t}$-table. This means that $\mathrm{H} 0$ is rejected and $\mathrm{H} 3$ is accepted, then there is a significant influence between the scope of work on good corporate governance. Thus the hypothesis which states that there is an influence between the Scope of Work on Good Corporate Governance can be accepted. That the scope of work of auditors greatly influences the implementation of Good Corporate Governance at PT Jasa Raharja (Persero) so that the creation of good corporate governance within the company.

This occurs because the Internal Audit in terms of checking the suitability of policies, plans, procedures, regulations and applicable Laws has been implemented properly and has examined the use of resources economically and efficiently.

This result is in line with research conducted by Radu Florea \& Ramona Florea (2013) stating that the scope of internal audit work is an important management tool to assist and support company management in identifying and managing risks that bring added value to company activities. Internal Audit is in an interdependent relationship in corporate governance.

\section{The Effect of Examination on Good Corporate Governance}

Based on the results obtained it can be analyzed that the direction of the relationship between the Examination and Good Corporate Governance is positive, there is written 1,894 meaning that when there is an increase in the Examination it will improve Good Corporate Governance.

Based on the provisions previously stated, where the t-count is 3,736 and the degree of freedom (n-k-1) or 85-4-1 = 80 is obtained by the t-table number 1.990 , so that the $t$-count $>t-$ table. This means that $\mathrm{H} 0$ is rejected and $\mathrm{H} 4$ is accepted, then there is a significant influence between the Examination of Good Corporate Governance. Thus the hypothesis which states that there is an influence between the Examination of Good Corporate Governance can be accepted. That the Examination carried out by auditors greatly influences the implementation of Good Corporate Governance in PT. Jasa Raharja (Persero) so as to create good corporate governance in the company.

This happens because all the audit operations have been very good and the Internal Audit has made planning of the examination, testing and evaluating the information carried out by collecting, analyzing, interpreting and proving the truth of the information properly. 
These results are in line with research conducted by Muh. Yusuf Q. and A. Rezeki Asriani (2015) stated that the influence of the role of the Internal Audit Examination had a significant positive effect on the implementation of Good Corporate Governance. Because the existence of the SPI function guarantees the effectiveness of internal control and is a strategic partner in improving company management activities and encouraging governance processes.

\section{CONCLUSION AND SUGGESTION}

Based on the data that has been collected, processed and analyzed, the researchers obtain conclusions from the results of testing the hypothesis as follows:

1) The Effect of Independence on Good Corporate Governance

Independence has a positive effect on Good Corporate Governance because Internal Audit has been very objective in the sense of having an objective, impartial mental attitude and avoiding the possibility of conflict of interest so that in carrying out the internal control process of the company, auditor independence is very good for determining company performance be better.

2) The Effect of Professional Capability on Good Corporate Governance

The influence of Professional Capability has a positive effect on Good Corporate Governance because Internal Audit already has the knowledge, skills and scientific disciplines that are important in carrying out audits and has complied with applicable audit standards. Auditors who have professional abilities can improve Good Corporate Governance.

3) The Effect of Work Scope on Good Corporate Governance

The effect of the scope of work has a positive effect on Good Corporate Governance because Internal Audit in terms of checking the suitability of policies, plans, procedures, regulations and applicable laws has been implemented well and has examined the use of resources economically and efficiently. The scope of work of qualified auditors will have a positive influence and can improve the company's Good Corporate Governance.

4) The Effect of Examination on Good Corporate Governance

The influence of the Examination has a positive effect on Good Corporate Governance because all the implementation of the audit has been very good and the Internal Audit has made planning audit, testing and evaluating information carried out by collecting, analyzing, interpreting and proving the truth of the information properly. A good Examination has a positive influence and can improve the company's Good Corporate Governance.

\section{REFERENCE}

- Ayuthia Ramadhani Herman, Andreas dan Hardi. 2013. Pengaruh Faktor-faktor Audit Internal terhadap Pelaksanaan Good Corporate Governance. Jurnal Akuntansi Keuangan dan Bisnis Vol. 6

- Arens, Alvin A. 2015. Auditing and assurance services : An integrated approach, Jakarta, Erlangga

- Avianti, Ilya. 2005. Peran Pengendalian Internal dalam Meningkatkan Good Corporate Governance. Jurnal Bisnis dan Manajemen Vol IV No.1

- Cangemi dan Singleton. 2003. Managing the Audit Function. Salemba Empat. Jakarta

- Cristina Bota Avram, Ioan Popa dan Cristina Stefanescu. 2010. Methods of Measuring the Performance of Internal Audit, The Annals of the "Stefan cel Mare" University of Suceava. Fascicle of the Faculty of Economics and Public Administration Vol. 10 
- Dewan SPAP Ikatan Akuntan Publik Indonesia. Kompartemen Akuntan Publik. 2001. Standar Professional Akuntan Publik per 1 Januari 2001. Jakarta : Salemba Empat

- Dr. Jane J. Zhang. 2009. Corporate Governance, Internal Control and the Role of Internal Auditors - A Survey of Chinese Managers, cn.ckgsb.com School of Accounting, Economics and Statistics Edinburgh Napier University Business School Craiglockhart Campus.

- Gusnardi. 2008. Analisis Faktor Audit Internal dan Pengaruhnya terhadap Pelaksanaan Good Corporate Governance. Ekuitas Vo. 12 No. 3 ISSN 1411-0393

- Imam Ghozali. 2013. Aplikasi Multivariate Dengan Program SPSS 21 Update PLS Regresi ( $7^{\text {th }}$ Ed). Semarang : Badan Penerbit Universitas Dipenogoro

- Iskander, Magdi R. dan Nadereh Chamlou. 2000. Corporate Governance: A Framework for Implementation. The International Bank for Reconstruction and Development. The World bank.

- Konsorsium Organisasi Profesi Audit Internal, 2003. Standar Profesi Audit Internal. Yayasan Pendidikan Internal Audit

- Lela Nurlela Wati. 2017. Metodelogi Penelitian Bisnis Terapan Aplikasi SPSS, EVIEWS, Smart PLS dan AMOS. Jakarta : CV Mujahid Press

- Martono, Nanang. 2015. Metode Penelitian Sosial. Jakarta: PT. Raja Grafindo Persada

- Mayangsari, Sekar. 2003. Pengaruh Keahlian Audit dan Independensi terhadap Pendapat Audit: Sebuah Kuasieksperimen. Jurnal Riset Akuntansi Indonesia Vol 6 No.1

○ Messier, Wiliam F.jR.Steven M Glover Dan Donglas F.Prawitt. 2005 Auditing \& Asurance Service A Service Systematic Approach. Edisi 4. Penerjemah Nuri Hinduan, Salemba Empat, Buku II, Jakarta. Mulyadi, 2002. Auditing, Buku Edisi 6 Jilid 3, Salemba Empat Jakarta

○ Moh Nazir. 2011. Metode Penelitian. Cetakan 6. Bogor: Penerbit Ghalia Indonesia

- Peraturan Menteri Negara Badan Usaha Milik Negara Nomor : PER - 01/MBU/2011 Tentang Penerapan Tata Kelola Perusahaan Yang Baik (Good Corporate Governance) Pada Badan Usaha Milik Negara

○ Ratliff,1996, The Internal Auditing principles \& Techniques, $2^{\text {nd }}$ edition, USA

- Radu Florea \& Ramona Florea. 2013. Internal Audit and Corporate Governance, Economy Transdisciplinary Cognition Vol. 16 Issue 1.

- Susilawati, Christine Dwi Karya,S.E.,M.Si.,Ak. 2013." Peranan Audit Intern Dalam Penerapan Good Corporate Governance Yang Efektiv Pada PT.XYZ, Bandung'’. Jurnal Ilmiah Akuntansi ISSN: 2086-4159 Nomor 10 Tahun ke-3 Bulan Mei-Agustus 2013

- Tugiman, Hiro. 2004. Pengendalian Intern yang Buruk Menjadi Penyebab Utama Indonesia Menjadi Negara Terkorup. Disampaikan pada Pidato Pengukuhan Guru Besar Universitas Widyatama

- Tugiman, Hiro. 2004. Peran Auditor Internal dalam Menunjang GCG pada BUMN di Indonesia

- Tugiman, Hiro. 2006. Pandangan Baru Internal Auditing. Cetakan Kesembilan Penerbit Kanisius, Yokyakarta.

○ Yenti, Yona. E., Efrizal Sofyan. 2013. "Pengaruh Konservatisme Akuntansi Terhadap Peniaian Ekuitas dengan Good Corporate sebagai Variabel Pemoderasi". WRA, Vol.1, No.2 